Brief reports

\title{
Inhibition of defensin $A$ and cecropin $A$ responses to dengue virus 1 infection in Aedes aegypti
}

\author{
Yda Méndez, César Pacheco, Flor Herrera \\ Instituto de Investigaciones Biomédicas "Dr. Francisco Triana Alonso," Facultad de Ciencias de la \\ Salud, Universidad de Carabobo, Maracay, Aragua, Venezuela
}

Introduction: It is essential to determine the interactions between viruses and mosquitoes to diminish dengue viral transmission. These interactions constitute a very complex system of highly regulated pathways known as the innate immune system of the mosquito, which produces antimicrobial peptides that act as effector molecules against bacterial and fungal infections. There is less information about such effects on virus infections.

Objective: To determine the expression of two antimicrobial peptide genes, defensin $A$ and cecropin A, in Aedes aegypti mosquitoes infected with DENV-1.

Materials and methods: We used the $F_{1}$ generation of mosquitoes orally infected with DENV-1 and real-time PCR analysis to determine whether the defensin A and cecropin $A$ genes played a role in controlling DENV-1 replication in Ae. aegypti. As a reference, we conducted similar experiments with the bacteria Escherichia coli.

Results: Basal levels of defensin A and cecropin A mRNA were expressed in uninfected mosquitoes at different times post-blood feeding. The infected mosquitoes experienced reduced expression of these mRNA by at least eightfold when compared to uninfected control mosquitoes at all times post-infection. In contrast with the behavior of DENV-1, results showed that bacterial infection produced up-regulation of defensin and cecropin genes; however, the induction of transcripts occurred at later times (15 days).

Conclusion: DENV-1 virus inhibited the expression of defensin A and cecropin A genes in a wild $A$ e. aegypti population from Venezuela.

Received: 01/04/2020

Accepted: 19/08/2020

Published: $28 / 08 / 2020$

Citation:

Méndez Y, Pacheco C, Herrera F. Inhibition of defensin $A$ and cecropin $A$ responses to dengue virus 1 infection in Aedes aegypti. Biomédica. 2021;41:161-7.

https://doi.org/10.7705/biomedica.5491

\section{Corresponding author:}

Flor Herrera, Edificio BIOMED, Final callejón Cecilio Acosta, Avda. Las Delicias, Maracay, Aragua, Venezuela

Telephone: (58-243) 242 5822, fax: (58-243) 242

5333

flormhq@gmail.com

\section{Author contributions:}

Yda Méndez conducted the experiments. César Pacheco designed the figures and supplementary material.

Flor Herrera conceived the study and was in charge of its overall direction and the writing of the manuscript.

All authors discussed the results and contributed to the final manuscript.

Funding:

This work was financed by the Fondo Nacional de Ciencia, Tecnología e Innovación, Venezuela (grant number 2008000911-1).

Conflicts of interest:

None declared.
Key words: Aedes aegypti; dengue virus; alpha-defensins; cecropins; Escherichia coli.

Inhibición de las respuestas de defensina $A$ y cecropina $A$ contra la infección del virus dengue 1 en Aedes aegypti

Introducción. Es esencial determinar las interacciones entre los virus y los mosquitos para disminuir la transmisión viral. Estas interacciones constituyen un sistema muy complejo y muy regulado conocido como sistema inmunitario innato del mosquito, el cual produce péptidos antimicrobianos, moléculas efectoras que funcionan contra las infecciones bacterianas y fúngicas; se tiene poca información de su acción sobre los virus.

Objetivo. Determinar la expresión de dos genes AMP (defensina $A$ y cecropina $A$ ) en mosquitos Aedes aegypti infectados con el virus DENV-1.

Materiales y métodos. Se infectaron oralmente mosquitos de generación $F_{1}$ con DENV-1 y mediante el análisis con PCR en tiempo real se determinó el potencial papel de los genes defensina A y cecropina $A$ en el control de la replicación del DENV-1 en Ae. aegypti. Como referencia, se infectaron mosquitos con Escherichia coli.

Resultados: Los mosquitos no infectados expresaron niveles basales de los ARNm de los genes defensina $A$ y cecropina $A$ en diversos momentos después de la alimentación. Los mosquitos infectados experimentaron una reducción, por lo menos, de ocho veces en la expresión de estos ARNm con respecto a los mosquitos de control en todo el periodo posterior a la alimentación. En contraste con el comportamiento del virus DENV1, los resultados mostraron que la infección bacteriana produjo una regulación positiva de los genes defensina y cecropina; sin embargo, la inducción de los transcritos ocurrió tardíamente (15 días).

Conclusión. El virus DENV-1 inhibió la expresión de los genes defensina $A$ y cecropina $A$ en una población silvestre de Ae. aegypti en Venezuela.

Palabras clave: Aedes aegypti; virus del dengue; alfa-defensinas; cecropinas; Escherichia coli. 
In Venezuela, dengue is the most important arboviral disease affecting humans, and its incidence and prevalence rise annually (1). Until now, there is not a vaccine to avoid DENV infections and, therefore, vector control is the only way to restrain these disease risks (2).

Arboviruses such as DENV have to go through a series of critical steps that demand their interplay with different tissues, which lasts for days or weeks until transmission can occur (2-4). These tissues represent barriers that restrict virus growth through, among others, immune molecules with antipathogenic activity that belong to a very complex system of highly regulated pathways called the innate immune system of mosquitos. Toll, IMD, JAK/STAT, and RNAi are the primary immune signaling pathways (2-5).

Different strategies to diminish viral transmission have been considered, among them, the use of genetically engineered vectors and natural symbionts like Wolbachia $(6,7)$. Any strategy to control dengue transmission should consider the interactions between viruses and mosquitoes, especially, their innate immune system.

Toll and IMD pathways produce effector molecules such as the antimicrobial peptides, low molecular-weight proteins well known for their action against bacterial and fungal infections, although there is less information regarding their effect on viral infections. Reports suggest that dengue virus infection is controlled by the toll pathway in mosquitoes (8) and that together with the IMD pathways they upregulate the Sindbis (9) and the DENV-2 viruses in mosquitoes $(10,11)$. However, other studies have evidenced the inhibition of toll's innate immune response in salivary glands infected by DENV-2 with 3'UTR substitutions associated with high epidemiological fitness and enhanced production of infectious saliva (12).

In our study, we found that the expression of defensin $A$ and cecropin $A$ genes, two antimicrobial peptide genes mediated by the toll pathway, was significantly reduced in Ae. aegypti mosquitoes infected with DENV-1 suggesting that the infection progresses by suppressing the toll pathway.

\section{Materials and methods}

\section{Mosquito collection}

We collected Ae. aegypti mosquitoes as larvae from Maracay, Venezuela, and then obtained their $F_{1}$ generation.

\section{Dengue virus, bacteria, and infection processes}

We used a DENV-1 isolate (LAR23644) recovered from a patient in Maracay in 2007 for the infection assays. Viruses were serially passaged in Ae. albopictus $\mathrm{C} 6 / 36$ cells, the infected supernatants were then harvested, titered via plaque-forming assay, and frozen at $-80^{\circ} \mathrm{C}$. The viral titer was 4,8 $x 10^{5} \mathrm{PFU} / \mathrm{ml}$. For oral infection experiments, we mixed viral stocks $1: 1$ with human red blood cells washed with PBS and fed to mosquitoes (sugar starved for $24 \mathrm{~h}$ ) via membrane feeders. Some groups of mosquitoes were fed only on human red blood cells. Immediately post-feeding, fully engorged specimens were transferred to new cages held under standard rearing conditions and provided with sucrose.

At different times after feeding, $\approx 30$ mosquitoes were collected each time. At early times ( 5 and 24 hours) we checked if the virus was inactivated by some 
antiviral defense mechanism present in the mosquitoes' guts while at later times (10 and 15 days), we aimed at detecting viral replication in their bodies.

To determine the percentage of virus infection, dissemination, and potential transmission in the vector, 50 individual mosquitoes' abdomen (fed with the virus similarly as before and collected 15 days later) were dissected to check for infection, their legs and wings for dissemination, and their salivary glands for potential transmission. It is known that the only way to measure transmission is by analyzing the saliva of the mosquitoes, for which the viruses in these last tissues are potentially transmittable (13). Prior to their lysis, all the tissues were washed three times with $200 \mu \mathrm{l}$ of PBS to discard any contamination. Mosquitoes were stored at $-80^{\circ} \mathrm{C}$.

Similar infections were carried out with $E$. coli cultured in $\mathrm{OD}_{600} 0.8$, pelleted, washed, and resuspended in PBS. The bacteria culture was mixed with human red blood cells in equal proportions, and then we applied the methodological procedure used for viral infection.

\section{Detection and typing of dengue viruses in Aedes aegypti}

RNA extraction, detection, and typing of dengue viruses in pools of whole bodies or in dissected samples of Ae. aegypti were performed according to Urdaneta, et al. (14).

\section{Quantitative RT-PCR (qPCR) for measuring gene expression}

Gene expression was determined by relative quantification relating the qPCR signal of the defensin A or cecropin A gene transcript in a mosquito group fed on virus or bacteria mixed with human red blood cells and that of a control group (calibrator) fed only on human red blood cells. qPCR was conducted in a reaction volume of $25 \mu \mathrm{l}$ in a 96-well plate containing $0.5 \mu \mathrm{g}$ of template based on the initial RNA concentration and $200 \mathrm{nM}$ forward and reverse primers using real-time Go Taq qPCR ${ }^{\text {TM }}$ (Promega Corporation, USA) on a 7500 Real-Time PCR System $^{\mathrm{TM}}$ (Applied Biosystems, Massachusetts, USA) using the following program: 2 minutes of preincubation at $95{ }^{\circ} \mathrm{C}$ followed by 4030 -s cycles at $95^{\circ} \mathrm{C}$ and one minute at $60^{\circ} \mathrm{C}$. The designed specific primers used were: Defensin A gene (sense: 5'-AACTGCCGGAGGAAACCTAT-3'; antisense: 5'-TCTTGGAGTTGCAGTAACCT-3') and cecropin A gene (sense: 5'-CGAAGTTATTTCTCCTGATCG-3'; antisense: 5'-AGCTACAACAGGAAGAGCC-3'). To normalize the data, we used the $\alpha$-tubulin gene (sense: 5'-GCGTGAATGTATCTCCGTGC-3'; antisense: 5'-AGCTACAACAGGAAGAGCC-3') s an endogenous reference.

We assessed $\alpha$-tubulin, defensin $A$, and cecropin $A$ primer pairs and we found the following for each: The observed efficiency was near to $100 \%$ (figure $1 S)$, the amplification specificity was displayed through the production of a unique peak in the melt-curve analysis (figure 2S), which was corroborated by sequencing the PCR products from each gene in both directions using the PCR primers (data not shown). The sequencing reactions were performed with the ABI PRISM BigDye Terminator ${ }^{\mathrm{TM}}$, version 3.1 Cycle Sequencing Kit on an Applied Biosystems genetic analyzer, Model ABI 3130XL. Therefore, the $2^{-\Delta \Delta C t}$ method of relative quantification was used to appraise relative gene expression.

We used the control and virus-infected pool samples ( $\approx 30$ mosquitoes/ pool) at different times after feeding ( $5 \mathrm{~h}, 24 \mathrm{~h}, 10$ days, and 15 days) in the qPCR reaction (a total of 8 pools: $\approx 240$ mosquitoes). The control values were 
very close at all times, so we took their average as the calibrator. Each qPCR experiment was repeated three times with three replicates of each one. Similar experiments were carried out with E. coli. The average and standard deviation (SD) of the $C_{T} s$ from the three replicates were determined and the average was only approved if the SD was $<0.38(15)$. Repeatability and reproducibility were calculated by a percent coefficient of variance (\% CV) within and between assays respectively (tables $3 S$ ).

We calculated $\mathrm{N}$-fold copy numbers of the Ae. aegypti defensin $\mathrm{A}$ and cecropin $A$ gene transcripts relative to the control in each assay using geometric means for the three experiments.

\section{Results}

\section{Stability and replication of DENV-1}

We determined whether the DENV-1 was stable at early post-infection (dpi) times ( 5 and 24 hours) and replicated at later ones (10 and 15 days) in the mosquitoes using RT-PCR amplification followed by agarose gel electrophoresis analysis of the products. Figure 1 shows the presence of DENV-1 with the cDNA band at the 482 bp position at all time points under study. The replication was further corroborated in the dissected samples of 50 individual mosquitoes with $70 \%$ and $100 \%$ viral infection and a dissemination efficiency 15 days post-infection. Regarding the virus present in the salivary glands, it also replicated (45\%) and evidenced potential transmission efficiency (Table 9S).

\section{Inhibition of defensin and cecropin mRNA by DENV-1}

The relative expression levels of defensin $A$ and cecropin $A$ genes in DENV-1-infected Ae. aegypti mosquitoes as compared to the calibrator are shown in figure 2A with both mRNA detectable in control mosquitoes; however, a significant decrease in abundance occurred at all time points measured with at least five to eight-fold fewer amounts of defensin and cecropin mRNA, respectively, in mosquitoes infected with DENV-1.

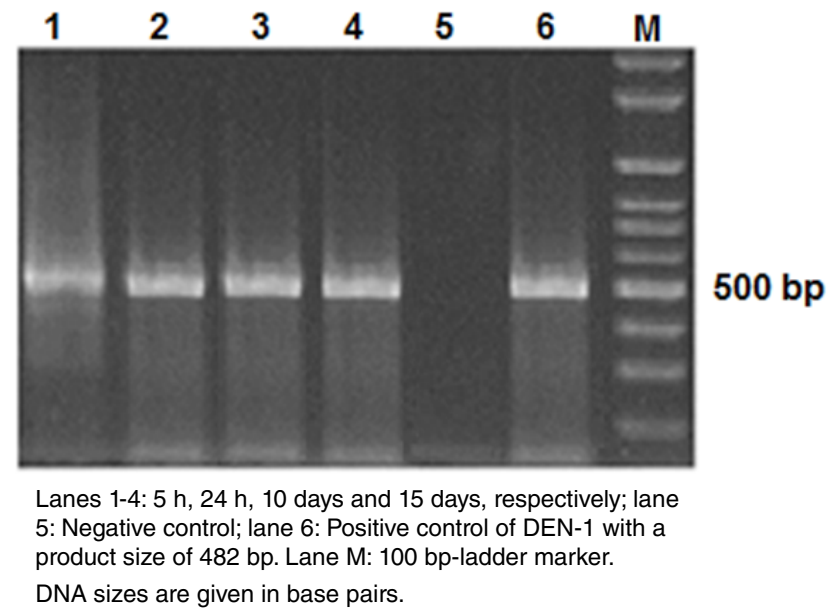

Figure 1. Detection of DEN-1 in Aedes aegypti by gel electrophoresis on a $2 \%$ agarose gel. DNA amplicons generated by RT-PCR of the RNA extracted from dengue viruses in Aedes aegypti at different times post infection. 

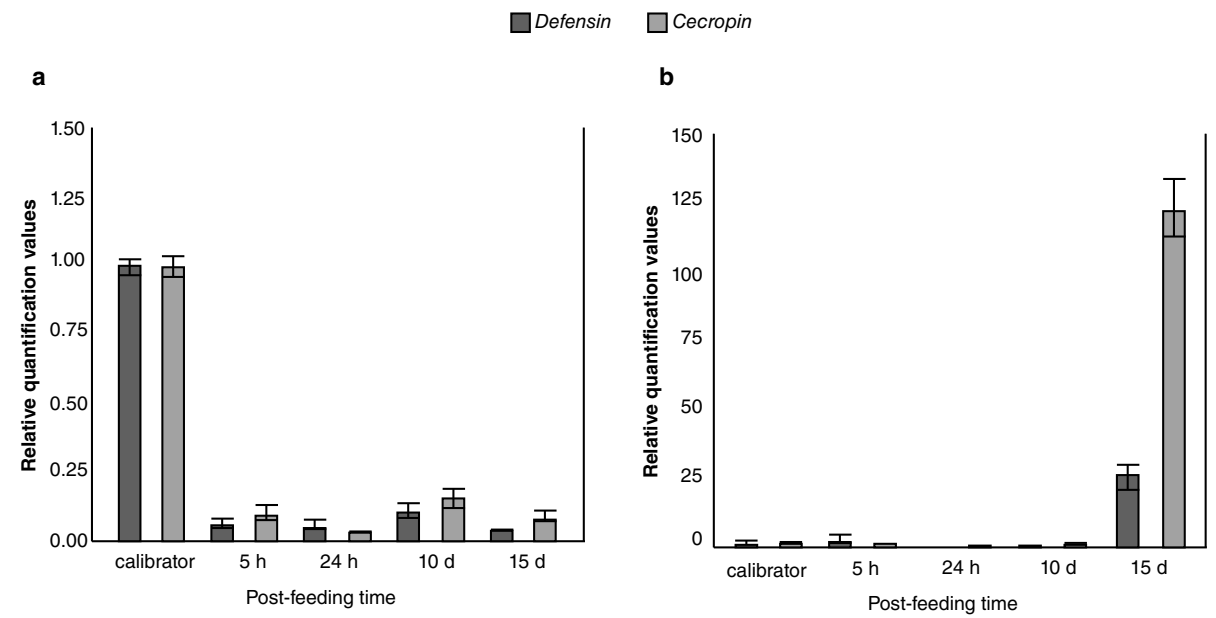

Figure 2. Comparison of immune responses to DENV-1 and Escherichia coli bacteria in fieldcollected Aedes aegypti. Averaged data from three independent real-time qPCR experiments were used to assess the expression of each of the selected immune genes in the Aedes aegypti mosquitoes infected with the DEN-1 virus (a) or Escherichia coli bacteria (b) with the host a-tubulin as an internal reference control to normalize the data. For each pathogen, the control values for both genes at all the time points were very similar. In every case, the average of all these values was used as the calibrator. The $2-\Delta \Delta C T$ method was used to calculate fold change for each gene.

\section{Induction of defensin and cecropin mRNA by bacteria}

The response of the field population of Ae. aegypti mosquitoes to bacteria was contrary to the previously described viral response given that, as expected, the bacterial infection did not produce down-regulation in any of the genes (figure 2B); however, the induction of transcripts occurred at later times (15 days).

\section{Discussion}

There is a discrepancy regarding the reaction of mosquitoes' immune system in the presence of DENV-1. The response may be stimulation $(2,8,10,11)$ or suppression in vivo $(9,16-18)$ and in vitro $(19,20)$. Such discrepancy probably depends on the viral strain used, the genetic history of the vector, and the mode of transmission $(3,21)$. We found a reduced expression of defensin $A$ and cecropin $A$ genes using the $F_{1}$ generation of wild mosquitoes infected with DENV-1. Similar results were reported with DENV-2-infected field Ae. aegypti populations (6).

The specific molecular mechanism by which DENV acts remains uncharacterized. The virus may be able to knock down the expression of some factor needed to induce the expression of defensin and cecropin mRNA, similar to the role reported for the AeFaDD protein in Ae. aegypti (22). Alternatively, the DENV may directly target and inhibit the transcription of both genes.

The suppression of the innate immune responses of mosquitoes found in this study was time-independent contrary to other reports using similar times: $1,2,7$, and 14 days (17), which implies that DENV may exert continuous immunomodulatory activity in mosquitoes, or for some period of time. This is critical for defining the vector competence of local mosquitoes, as well as dengue transmission intensity in a particular area. 
As expected, the bacterial infection did not produce down-regulation of the defensin and cecropin genes $(23,24)$; however, the induction of the transcripts occurred at later times (figure 2B). These data could indicate that the capacity of these wild $A e$. aegypti mosquitoes to mount a highly effective production of defensin and cecropin to control invading bacteria would take the time probably required to inactivate bacterial growth factors.

In conclusion, DENV-1 inhibits the expression of defensin A and cecropin $A$ genes in a wild $A$ e. aegypti population from Maracay city in Venezuela. The way the virus participates in this inhibitory mechanism and the viral effector molecules acting in it are still to be determined.

\section{Acknowledgments}

To Nancy Moreno for her critical reading of the manuscript; to Karem Flores and to the Dirección de Malariolog ía y Saneamiento Ambiental staff in Maracay, Estado Aragua, Venezuela, for the collection and rearing of mosquitoes; to Daria Camacho for providing the virus strain, and to Irene Bosch for assistance with the English language editing of this manuscript.

\section{References}

1. Ramos-Castañeda J, Barreto dos Santos F, Martínez-Vega R, Galvão de Araujo JM, Joint G, Sarti E. Dengue in Latin America: Systematic review of molecular epidemiological trends. PLoS Negl Trop Dis. 2017;11:e0005224. https://doi.org/10.1371/journal.pntd.0005224

2. Liu T, Xu Y, Wang X, Gu J, Yan G, Chen XG. Antiviral systems in vector mosquitoes. Dev Comp Immunol. 2018;83:34-43. https://doi.org/10.1016/j.dci.2017.12.025

3. Sim S, Jupatanakul N, Dimopoulos G. Mosquito immunity against arboviruses. Viruses. 2014;6:4479-504. https://doi.org/10.3390/v6114479

4. Wang $Y$, Chang $M$, Wang $X$, Zheng AH, Zou Z. The immune strategies of mosquito Aedes aegypti against microbial infection. Dev Comp Immunol. 2018;83:12-21. https://doi.org/10.1016/j.dci.2017.12.001

5. Blair C. Mosquito RNAi is the major innate immune pathway controlling arbovirus infection and transmission. Future Microbiol. 2011;6:265-77. https://doi.10.2217/fmb.11.11

6. Carvalho-Leandro D, Ayres C, Guedes D, Suesdek L, Melo-Santos MA, Oliveira CF. Immune transcript variations among Aedes aegypti populations with distinct susceptibility to dengue virus serotype 2. Acta Trop. 2012;124:113-9. https://doi.org/10.1016/j.actatropica.2012.07.006

7. Mains J, Brelsfoard C, Rose R, Dobson S. Female adult Aedes albopictus suppression by Wolbachia-infected male mosquitoes. Sci Rep. 2016 6:33846. https://doi.org/10.1038/srep33846

8. Xi Z, Ramírez JL, Dimopoulos G. The Aedes aegypti toll pathway controls dengue virus infection. PLoS Pathog. 2008;4:e1000098. https://doi.org/10.1371/journal.ppat.1000098

9. Sanders HR, Foy BD, Evans AM, Ross LS, Beaty BJ, Olson KE, et al. Sindbis virus induces transport processes and alters expression of innate immunity pathway genes in the midgut of the disease vector, Aedes aegypti. Insect Biochem Mol Biol. 2005;35:1293-307. https://doi.org/10.1016/j.ibmb.2005.07.006

10. Luplertlop N, Surasombatpattana P, Patramool S, Dumas E, Wasinpiyamongkol, Saune L, et al. Induction of a peptide with activity against a broad spectrum of pathogens in the Aedes aegypti salivary gland, following infection with dengue virus. PLoS Pathog. 2011;7:e1001252. https://doi.org/10.1371/journal.ppat.1001252

11. Wasinpiyamongkol L, Missé $\mathrm{D}$, Luplertlop $\mathrm{N}$. Induction of defensin response to dengue infection in Aedes aegypti. Entomol Science. 2015;18:199-206. https://doi.org/10.1111/ens.12108

12. Pompon J, Manuel M, Ng G, Wong B, Shan C, Manokaran G, et al. Dengue subgenomic flaviviral RNA disrupts immunity in mosquito salivary glands to increase virus transmission. PLoS Pathog. 2017;13:e1006535. https://doi.org/10.1371/journal.ppat.1006535

13. Mellor PS. Replication of arboviruses in insect vectors. J Comp Path. 2000;123:231-47. https://doi.org/10.1053/jcpa.2000.0434 
14. Urdaneta L, Herrera F, Pernalete M, Zoghbi N, Rubio-Palis Y, Barrios R, et al. Detection of dengue viruses in field-caught Aedes aegypti (Diptera: Culicidae) in Maracay, Aragua state, Venezuela by type-specific polymerase chain reaction. Infect Genet Evol. 2005;5:177-84 https://doi.org/10.1016/j.meegid.2004.09.004

15. Pfaffl MW. A new mathematical model for relative quantification in real-time RT-PCR. Nucleic Acids Res. 2001;29:2002-7. https://doi.org/10.1093/nar/29.9.e45

16. Fragkoudis R, Chi Y, Siu R, Barry G, Attarzadeh-Yazdi G, Merits A, et al. Semliki Forest virus strongly reduces mosquito host defense signaling. Insect Mol Biol. 2008;17:647-56. https://doi.org/10.1111/j.1365-2583.2008.00834.x

17. Colpitts T, Cox J, Vanlandingham D, Feitosa F, Cheng G, Kurscheid S, et al. Alterations in the Aedes aegypti transcriptome during Infection with West Nile, dengue and yellow fever viruses. PLoS Pathog. 2011;7: e1002189. https://doi.org/10.1371/journal.ppat.1002189

18. Chang-Hyun K, Muturi E. Effect of larval density and Sindbis virus infection on immune responses in Aedes aegypti. J Insect Physiol. 2013;59:604-10. https://doi.org/10.1016/j.jinsphys.2013.03.010

19. Lin C, Chou C, Hsu Y, Lien J, Wang Y, Chen S, et al. Characterization of two mosquito STATs, AaSTAT and CtSTAT. Differential regulation of tyrosine phosphorylation and DNA binding activity by lipopolysaccharide treatment and by Japanese encephalitis virus infection. J Biol Chem. 2004;279:3308-17. https://doi.org/10.1074/jbc.M309749200

20. Sim S, Dimopoulos G. Dengue virus inhibits immune responses in Aedes aegypti cells PLoS One. 2010;5 e10678. https://doi.org/10.1371/journal.pone.0010678

21. Lambrechts $\mathrm{L}$, Scott T. Mode of transmission and the evolution of arbovirus virulence in mosquito vectors. Proc R Soc B. 2009;276:1369-78. https://doi.org/10.1098/rspb.2008.1709

22. Cooper D, Chamberlain C, Lowenberger C. Aedes FADD: A novel death domain-containing protein required for antibacterial immunity in the yellow fever mosquito, Aedes aegypti. J Insect Biochem Mol Biol. 2009;39:47-54. https://doi.org/10.1016/j.ibmb.2008.09.011

23. Bartholomay L, Michel K. Mosquito Immunobiology: the intersection of vector health and vector competence. Annu Rev Entomol. 2018;63:145-67. https://doi.org/10.1146/annurev-ento-010715-023530

24. Lowenberger C. Innate immune response of Aedes aegypti. Insect Biochem Mol Biol. 2001;31:219-22. https://doi.org/10.1016/s0965-1748(00)00141-7 